\title{
MENINGKATKAN KEMAMPUAN KEPALA SEKOLAH DALAM MENYUSUN PROGRAM SUPERVISI AKADEMIK MELALUI PENDAMPINGAN DAN SUPERVISI MANAJERIAL
}

\author{
Dwi Astarini \\ Pengawas Sekolah Dinas Pendidikan Kota Mojokerto \\ Jl. Benteng Pancasila Nomor 244 Kota Mojokerto \\ E-mail:dwi_astarini9@yahoo.co.id
}

\begin{abstract}
The purpose of this research is to improve the ability of school principals in preparing academic supervision programs through mentoring and managerial supervision. This study is intended to improve the performance of teachers in improving basic competence and performance as a professional teacher. The draft before conducting research, compiling performance assessment instruments principals in the description of the activities in the group supervision in KKKS forum. This study has two cycles through mentoring and managerial supervision conducted by researchers in an attempt to improve the ability of the principal. Results of research conducted during two cycles and based the entire discussion and analysis has been done be concluded to see the ability of school principals in preparing the program of the academic supervision necessary technical support and managerial supervision by supervisors. The results of the implementation of the first cycle and the second cycle by a watchdog have shown improvement. Criteria and instruments increase the ability of principals has been achieved up to $87.5 \%$ on the principal in elementary Cluster 4 Districts Magersari Mojokerto.
\end{abstract}

\begin{abstract}
Abstrak: Tujuan penelitian ini adalah untuk meningkatkan kemampuan kepala sekolah dalam menyusun program supervisi akademik melalui pendampingan dan supervisi manajerial. Penelitian ini dimaksudkan untuk meningkatkan kinerja guru dalam meningkatkan kompetensi dasar dan performanya sebagai guru profesional. Rancangan sebelum mengadakan penelitian, menyusun instrumen penilaian kinerja kepala sekolah dalam uraian kegiatan dalam supervisi kelompok di forum KKKS. Penelitian ini terdapat dua siklus melalui pendampingan dan supervisi menejerial yang dilakukan peneliti dalam upaya untuk meningkatkan kemampuan kepala sekolah. Hasil penelitian yang telah dilakukan selama dua siklus dan berdasarkan seluruh pembahasan serta analisis yang telah dilakukan diperoleh simpulan untuk melihat kemampuan kepala sekolah dalam menyusun program supervisi akademik perlu dilakukan pendampingan dan supervisi manajerial oleh pengawas. Hasil pelaksanaan Siklus I dan Siklus II oleh pengawas telah menunjukkan peningkatan. Kriteria dan instrumen peningkatan kemampuan kepala sekolah sudah dapat tercapai sampai 87,5\% pada kepala sekolah di Gugus SD 4 Kecamatan Magersari Kota Mojokerto.
\end{abstract}

Kata kunci: kemampuan kepala sekolah, program supervisi akademik, pendampingan, supervisi manajerial

Kepala sekolah sebagai pimpinan tertinggi di lembaganya, dituntut untuk memiliki kemampuan (ability) serta kompetensi yang berkaitan dengan tugasnya. Salah satunya adalah menyusun program supervisi akademik. Namun sesuai hasil pengamatan peneliti sebagai pengawas di wilayah kepengawasan yaitu di Gugus SD 4 Kecamatan
Magersari Kota Mojokerto, ditemukan kepala sekolah dalam melaksanakan supervisi akademik rata-rata tanpa adanya program yang tersusun dan terencana dengan baik, sehingga supervisi dilaksanakan apabila akan ada penilaian atau akreditasi saja; dan adanya kepala sekolah baru yang masih belum mengerti dan masih 
menyesuaikan diri dengan tugas-tugas yang dilaksanakan, sehingga masih dalam taraf belajar.

Berdasaran kedua landasan tersebut, pengawas perlu melakukan upaya dalam rangka meningkatkan kemampuan serta tugas pokok pendampingan bagi sekolah binaan. Hal ini berdasarkan tugas pokok dan fungsi pengawas sesuai Peraturan Menteri Pendidikan Nasional Nomor 12 Tahun 2007 tentang Standar Pengawas Sekolah / Madrasah, yaitu kompetensi pengawas sekolah dan madrasah meliputi enam kompetensi yakni kompetensi kepribadian, kompetensi supervisi akademik, kompetensi supervisi manajerial, kompetensi evaluasi pendidikan, kompetensi penelitian dan pengembangan, dan kompetensi sosial. Adapun rencana strategis yang akan peneliti lakukan adalah melakukan pendampingan dan supervisi manajerial, yang berkaitan dengan penyusunan program supervisi akademik yang disusun kepala sekolah. Dengan adanya pendampingan serta supervisi manajerial, diharapkan kepala sekolah dapat meningkatkan kemampuan dalam menyusun program supervisi akademik sehingga pelaksanaan supervisi akademik dapat terprogram dan terencana, yang nantinya akan berdampak pada kelancaran proses belajar mengajar serta terjaganya stabilitas pembelajaran.

\section{METODE}

Rancangan penelitian ini menggunakan jenis penelitian tindakan. Tahapan penelitian tindakan sekolah (PTS) yang digunakan ialah: perencanaan (planning); tindakan (acting); observasi (observing); dan refleksi (reflecting), kemudian berlanjut dengan perencanaan ulang (replanning), tindakan, observasi, dan refleksi untuk siklus berikutnya (Arikunto, 2011:16). Pelaksanaan PTS dimulai dengan siklus pertama yang terdiri dari tiga kegiatan yaitu pendampingan, pendampingan melalui diskusi kelompok, dan supervisi menejerial. Berdasarkan hasil refleksi Siklus I peneliti menganalisis data. Jika nilai rata-rata kemampuan kepala sekolah mencapai rata-rata kelompok $75 \%$, maka tindakan cukup hanya pada siklus pertama. Apabila nilai rata-rata kelompok belum mencapai 75\%, maka tindakan siklus I dilanjutkan ke siklus selanjutnya.

\section{HASIL}

\section{Hasil Siklus I \\ Perencanaan}

Rencana awal yang dilakukan pengawas adalah mengadakan kunjungan ke lembagalembaga binaan untuk memonitoring kepala sekolah sebagai manajer dan administrator, yaitu melihat secara langsung administrasi serta penyusunan program yang telah disusun oleh kepala sekolah, maupun yang belum menyusun serta identifikasi kesulitannya. Kemudian menyiapkan instrumen penilaian kinerja kepala sekolah yaitu pendampingan kepala sekolah terhadap penyusunan program supervisi akademik. Dengan instrumen tersebut akan dijadikan pedoman bagi pengawas dalam menilai sejauh mana kemampuan kepala sekolah dalam menyusun program supervisi akademik.

Selanjutnya menghadiri pertemuan Kelompok Kerja Kepala Sekolah (KKKS) Gugus SD 4 Kecamatan Magersari Kota Mojokerto, untuk mengadakan diskusi tentang penyusunan program supervisi akademik di masing-masing lembaganya. Pengawas menyampaikan hasil monitoring di masing-masing lembaga, namun tidak bermaksud untuk menunjukkan kekurangan masing-masing lembaga di forum tersebut, tetapi lebih pada memberikan evaluasi terhadap hasil monitoring untuk diketahui semua kepala sekolah sehingga secara bersama-sama akan mengetahui kekurangan serta akan menemukan solusi bersama-sama dalam forum tersebut dengan bimbingan pengawasan melalui kegiatan pendampingan.

\section{Pelaksanaan Tindakan}

Pelaksanaan tindakan yang dilakukan oleh pengawas dalam upaya untuk meningkatkan kemampuan kepala sekolah dalam penyusunan program supervisi akademik adalah:

\section{Kegiatan 1 Pendampingan}

Berdasarkan hasil monitoring terhadap delapan lembaga binaan dengan berpedoman pada instrumen, ditemukan permasalahan: (1) dalam menyusun program supervisi hanya ada tiga lembaga yang menyusun program supervisi akademik di awal tahun, sedangkan lima lembaga yang lainnya disusun 3 s.d. 5 bulan setelah 
kegiatan pembelajaran berjalan; (2) dalam membuat jadwal kegiatan supervisi kelas, hanya ada dua lembaga yang membuat jadwal secara rutin setiap bulannya, tiga lembaga membuat jadwal supervisi kelas 2 s.d. 3 bulan sekali, dan ada tiga lembaga yang mengadakan supervisi kelas apabila akan ada penilaian atau akreditasi saja; dan (3) dari hasil wawancara dalam melakukan supervisi kelas rata-rata hanya sebagai formalitas saja, tanpa memperhatikan mutu serta fungsi dari supervisi akademik itu sendiri.

Berdasarkan permasalahan tersebut, diadakan pendampingan melalui forum KKKS Gugus SD 4 Kecamatan Magersari Kota Mojokerto. Pendampingan dilakukan dengan memperhatikan kekurangan serta kelemahan dari masing-masing lembaga, dengan memberikan pedoman serta format yang seharusnya dibuat dan menurut prosedur dan tata cara penyusunan yang benar. Di sini pengawas akan memberikan pengarahan serta motivasi kepada kepala sekolah untuk dapat memperbaiki dan melaksanakan serta menyusun program supervisi akademik dengan baik dan benar sesuai dengan prosedur serta kebutuhan masing-masing lembaga.

\section{Kegiatan 2 Diskusi Kelompok}

Pendampingan dilaksanakan dengan cara diskusi kelompok dalam forum KKKS tersebut. Dalam forum tersebut akan dibahas bersama-sama hasil monitoring pengawas di masing-masing lembaga, apakah sudah dapat memperbaiki kekurangan maupun kesulitan yang dihadapi kepala sekolah dalam menyusun program supervisi akademik di lembaganya masing-masing. Apabila ada kesulitan, maka kepala sekolah langsung diberi kesempatan untuk mengungkapkannya, sehingaga dapat dipecahkan bersama-sama dalam forum tersebut dengan bimbingan pengawas.

\section{Kegiatan 3 Supervisi Manajerial}

Diskusi kelompok tersebut dilaksanakan dengan prosedur supervisi manajerial yang merupakan tugas dari pengawas, maka akan ditentukan pertemuan kembali dalam forum yang sama yaitu KKKS untuk bersama-sama menunjukkan hasil kinerja kepala sekolah dalam menyusun program supervisi akademik. Pengawas mengadakan supervisi manajerial untuk menilai hasil penyusunan program supervisi akademik yang terdiri atas membuat program supervisi akademik, menyusun jadwal supervisi kelas, melaksanakan supervisi kelas secara terprogram, dan melaksanakan rekapitulasi terhadap hasil supervisi kelas, serta mengadakan supervisi tindak lanjut terhadap hasil supervisi kelas. Pengawas dalam hal ini melaksanakan tugasnya sebagai kolaborator dan negosiator, sehingga pengawas ikut dalam proses perencanaan program supervisi akademik dan memberikan wacana sesuai dengan prosedur yang ada, kemudian saling berkoordinasi untuk memutuskan penyusunan program supervisi yang sesuai dengan lembaga, hal ini dengan tujuan pengembangan manajemen sekolah.

Selanjutnya pengawas sebagai asesor dalam mengidentifikasi kelemahan dan menganalisis potensi yang dimiliki kepala sekolah dalam menyusun program supervisi akademik. Namun untuk kepala sekolah yang masih baru, maka pengawas di sini bertindak sebagai pusat informasi bagi kepala sekolah baru untuk mendapatkan informasi yang belum diketahui sebagai upaya pengembangan mutu program supervisi akademik yang akan disusun. Dan yang terakhir adalah pengawas sebagai evaluator, dalam hal ini terhadap pemaknaan hasil pengawasan, yaitu menilai sejauh mana program yang telah dibuat untuk selanjutnya diadakan tindak lanjut apabila masih ada yang perlu diperbaiki lagi.

\section{Pengamatan}

Peneliti dalam pelaksanaan supervisi manajerial, melihat hasil penyusunan program supervisi akademik yang dihasilkan dari hasil pendampingan pada masing-masing lembaga binaan. Tentunya dalam forum KKKS tersebut akan ditemui kekuatan dan kelemahan dari masing-masing lembaga, namun dalam hal ini tidak bermaksud untuk membandingkan program supervisi akademik yang telah disusun oleh kepala sekolah dari lembaga yang satu dengan lembaga yang lain, melainkan pengawas melihat dari segi kebutuhan serta prosedur pembelajaran yang sebenarnya harus disupervisi.

\section{Refleksi Siklus I}

Berdasarkan hasil pendampingan hingga pelaksanaan supervisi manajerial, ditemukan 
beberapa kekuatan dan kelemahan dalam penyusunan program supervisi akademik. Adapun kekuatan yang ditemui pada saat pelaksanaan penelitian adalah: (1) adanya semangat yang tinggi dari kepala sekolah yang mampu menyusun program supervisi akademik di awal tahun pelajaran; dan (2) adanya kepala sekolah yang berusaha menyusun program supervisi akademik, walaupun belum sesuai prosedur. Sedangan kelemahan yang ditemui pada saat pelaksanaan penelitian adalah: (1) adanya kepala sekolah yang sudah lama dan berpengalaman, namun belum menyusun program supervisi akademik; (2) adanya kepala sekolah yang dengan sengaja mengadakan supervisi akademik, namun tanpa adanya program serta jadwal yang pasti, yaitu apabila akan ada penilaian atau akreditasi saja; dan (3) adanya kepala sekolah baru yang masih membutuhkan bimbingan dan program induksi lebih lanjut. Hasil pelaksanaan tindakan melalui pendampingan serta supervisi manajerial yang dilakukan oleh pengawas dan dengan melihat kekuatan dan kelemahan kepala sekolah tersebut dijadikan pijakan untuk memperbaiki tindakan pelaksanaan Siklus II.

\section{Indikator Keberhasilan}

Hasil pelaksanaan tindakan melalui pendampingan dan supervisi manajerial, hanya ada tiga lembaga yang mampu menunjukkan hasil penyusunan program akademik. Hasil penelitian Siklus I diketahui $62,5 \%$ kepala sekolah yang mampu menyusun program supervisi akademik dengan baik dan benar. Sehingga sesuai kompetensi kepala sekolah dalam pengembangkan kinerja keprofesiannya belum mencapai kompetensi minimal $75 \%$. Sehingga masih perlu dilakukan perbaikan di Siklus II.

\section{Hasil Siklus II}

\section{Perencanaan}

Rencana kegiatan awal pada siklus II seperti halnya dengan siklus I, Peneliti sebagai pengawas mengadakan supervisi kembali, namun langsung dalam forum KKKS Gugus 4 Kecamatan Magersari Kota Mojokerto, hal ini dimaksudkan untuk memberikan penyegaran kepada kepala sekolah terhadap kinerja yang sudah dilaksanakan terhadap guru-gurunya dilembaganya masingmasing dengan melaksanakan supervisi akademik dengan program yang telah disusun, maka untuk siklus II ditujukan untuk pemantapan, namun tetap untuk meningkatkan hasil dari pelaksanaan Siklus I.

\section{Pelaksanaan Tindakan}

Pelaksanaan dilakukan sesuai dengan perencanaan yang dibuat, Pengawas mengadakan pendampingan dengan tehnik kelompok pada forum KKKS Gugus SD 4 Kecamatan Magersari Kota Mojokerto. Pengawas dengan melihat secara langsung kekuatan serta kelemahan yang dihadapi oleh masing-masing lembaga yang ditemui pada pelaksanaan pendampingan dan supervisi manajerial di Siklus I, dapat dijadikan bahan pertimbangan melakukan perbaikan. Adapun kegiatan yang dilakukan pengawas adalah:

\section{Kegiatan 1 Pendampingan}

Seperti halnya pada Siklus I, kegiatan awal ialah mendiskusikan prosedur penyusunan program dengan melihat kekuatan serta kelemahan yang dihadapi oleh kepala sekolah yang ditemui pada pelaksanaan tindakan di Siklus I.

\section{Kegiatan 2 Diskusi Kelompok}

Mengadakan pendampingan dalam upaya peningkatan serta perbaikan program supervisi yang telah disusun oleh kepala sekolah, dimana tentunya setiap lembaga tidak sama dalam menyusun programnya, namun sama-sama untuk tujuan peningkatan pembelajaran. Sehingga antara lembaga yang satu dengan yang lain tidak sama pelaksanaan pendampingannya. Terutama untuk kepala sekolah yang baru maka ada program induksi khusus untuk pendampingannya.

\section{Kegiatan 3 Supervisi Manajerial}

Mengadakan supervisi manajerial untuk melihat hasil akhir dari hasil perbaikan yang dilakukan dengan pendampingan oleh pengawasan atas penyusunan program supervisi akademik masing-masing kepala sekolah yang terdiri dari membuat program supervisi akademik, menyusun jadwal supervisi kelas, melaksanaan supervisi kelas secara terprogram, dan melaksanakan rekapitulasi terhadap hasil 
supervisi kelas, serta mengadakan supervisi tindak lanjut terhadap hasil supervisi kelas. Di sini sudah tidak ada lagi perbaikan, semua program supervisi akademik yang disusun oleh kepala sekolah, sudah sesuai dengan kebutuhan masing-masing lembaga.

\section{Pengamatan}

Berdasarkan hasil pelaksanaan pendampingan dengan tehnik kelompok pada Siklus II ini, dapat dijabarkan hal-hal: (1) terdapat tujuh lembaga yang sudah dapat menunjukan hasil penyusunan program supervisi akademik yang sesuai prosedur dan kebutuhan masingmasing lembaga; dan (2) terdapat satu lembaga dengan kepala sekolah baru yang sudah berusaha membuat namun masih ada beberapa program yang perlu diperbaiki, namun sudah mampu menunjukkan hasil program supervisi akademik yang disusun.

\section{Refleksi Siklus II}

Berdasarkan hasil pengamatan yang dilakukan pengawas pada saat pendampingan dan supervisi manajerial, dengan hasil yang telah dijabarkan diatas maka pada Siklus II ini penelitian sudah diangap berhasil karena sudah ada tujuh lembaga yang sudah menyelesaikan penyusunan program supervisi akademik yang baik dan benar serta sesuai dengan kebutuahn lembaga masing-masing. Sehingga tidak perlu lagi dilakukan pelaksanaan Siklus III.

\section{Indikator Keberhasilan}

Berdasarkan hasil pengamatan pada Siklus II maka indikator keberhasilan pendampingan dan supervisi manajerial pada Siklus II adalah sebesar $87,5 \%$. Sudah ada tujuh lembaga yang sudah menyelesaikan program supervisi akademik dengan baik dan benar.

\section{PEMBAHASAN}

Berdasarkan hasil penelitian tindakan yang dilakukan di Gugus SD 4 Kecamatan Magersari Kota Mojokerto, hasilnya adalah: (1) pada Siklus I ditemukan bahwa masih ada tiga lembaga $(62,5 \%)$ yang dapat menyusun program supervisi akademik; dan (2) sedangkan pada hasil penelitian Siklus II sudah ada tujuh lembaga yang dapat menyusun program supervisi akademik (75\%). Sehingga dari hasil penelitian Siklus I dan Siklus II, penelitian ini sudah berhasil, karena sudah mencapai $87,5 \%$ indikator keberhasilannya, sehingga dapat disimpulkan bahwa dengan pendampingan dan supervisi manajerial yang dilakukan pengawas dapat meningkatkan kemampuan kepala sekolah dalam menyusun program supervisi akademik di Gugus SD 4 Kecamatan Magersari Kota Mojokerto.

Hal ini sesuai dengan pendapat Martam (2011) bahwa pengertian dari pendampingan yang terdapat pada merupakan proses interaksi timbal balik (tidak satu arah) antara individu, kelompok, atau komunitas yang mendampingi dan individu, kelompok, atau komunitas yang didampingi yang bertujuan memotivasi dan mengorganisasi individu, kelompok, atau komunitas dalam mengembangkan sumber daya dan potensi orang yang didampingi dan tidak menimbulkan ketergantungan terhadap orang yang mendampingi (mendorong kemandirian). Sesuai pula dengan tugas dari pengawas dalam melaksanakan fungsi supervisi manajerial, pengawas sekolah/madrasah berperan sebagai: (1) kolaborator dan negosiator dalam proses perencanaan, koordinasi, pengembangan manajemen sekolah; (2) asesor dalam mengidentifikasi kelemahan dan menganalisis potensi sekolah; (3) pusat informasi pengembangan mutu sekolah; dan (4) evaluator terhadap pemaknaan hasil pengawasan (Dirjen PMPTK Depdiknas, 2009).

\section{SIMPULAN DAN SARAN}

Berdasarkan hasil penelitian tindakan yang diperoleh dalam penelitian ini, dikemukakan simpulan penelitian, yaitu:

Pendampingan yang dilaksanakan dalam penelitian tindakan sekolah ini, telah berhasil meningkatkan kemampuan kepala sekolah dalam menyusun program supervisi akademik, khususnya kepala sekolah Gugus SD 4 Kecamatan Magersari Kota Mojokerto. Hal ini ditunjukkan dengan kemampuan kepala sekolah dalam membuat program supervisi akademik, menyusun jadwal supervisi kelas, melaksanaan supervisi kelas secara terprogram, 
dan melaksanakan rekapitualsi terhadap hasil supervisi kelas, serta mengadakan supervisi tindak lanjut terhadap hasil supervisi kelas.

Supervisi Manajerial dalam penelitian tindakan sekolah ini, telah berhasil meningkatkan kemampuan kepala sekolah dalam menyusun program supervisi akademik. Hal ini ditunjukkan dengan meningkatkan dorongan dan kemauan kepala sekolah dalam mengadakan perbaikan atas program yang telah disusun, melaksanakan diskusi dengan pengawas sebagai kolaborator dan negosiator serta melaporkan kepada pengawas sebagai asesor.

Melalui pendampingan dan supervisi manajerial yang dilaksanakan dalam penelitian tindakan sekolah ini, telah berhasil meningkatkan kemampuan kepala sekolah dalam menyusun program supervisi akademik secara merata di Gugus SD 4 Kecamatan Magersari Kota Mojokerto. Semua kepala sekolah menjadi termotivasi untuk melakukan penyusunan program supervisi akademik. Kepala sekolah yang baru juga mampu menyesuaikan diri dengan pekerjaan barunya, sehingga lebih termotivasi dan lebih aktif.

Pelaksanaan pendampingan dan Supervisi Manajerial tersebut dilakukan pada forum KKKS di Gugus 4 SD Kecamatan Magersari Kota Mojokerto. Pelaksanaan pendampingan dan supervisi manajerial tersebut dilaksanakan secara sistematis, dengan memperhatikan kebutuhan masing-masing lembaga.

Berdasarkan hasil penelitian ini, dikemukakan saran-saran, yaitu: (1) mengingat pendampingan dan supervisi manajerial dapat meningkatkan kemampuan kepala sekolah dalam menyusun program supervisi akademik, maka hendaknya para pengawas sekolah dasar yang lain juga menggunakan cara pendampingan dan supervisi manajerial; dan (2) untuk memperoleh hasil yang lebih baik, hendaknya dilakukan penelitian tindakan sekolah lanjutan, dengan sasaran yang lebih luas untuk memperoleh hasil yang lebih komprehensif. Untuk melaksanakan penelitian tindakan sekolah lanjutan, perlu dukungan dan kerja sama dengan pengawas yang lainnya guna pemerataan kemampuan gugus lain yang memiliki kesulitan yang sama, yaitu menyusun program supervisi akademik, sehingga seluruh kepala sekolah sekolah dasar dan madrasah Kota Mojokerto dapat menyusun program supervisi akademik.

\section{DAFTAR RUJUKAN}

Arikunto, S. 2011. Prosedur Penelitian: Suatu Pendekatan Praktik. Jakarta: Rineka Cipta.

Dirjen PMPTK Depdiknas. 2009. Dimensi Kompetensi Supervisi Manajerial (Bahan Belajar Mandiri Musyawarah Kerja Pengawas Sekolah). Jakarta: Depdiknas.

Martam, I. S. 2011. Pemulihan Psikososial Berbasis Komunitas untuk Pemulihan Trauma Pascakonflik. Jakarta: Yayasan Pulih.

Peraturan Menteri Pendidikan Nasional Nomor 12 Tahun 2007 tentang Standar Pengawas Sekolah / Madrasah, (Online). (http://www.depdiknas. go.id), diakses 26 Juli 2008. 